\title{
Electric cars as buffers in an electricity network
}

\author{
J. M. Vleugel ${ }^{1} \& \mathrm{~F} . \mathrm{Bal}^{2}$ \\ ${ }^{I} T U$ Delft, Civil Engineering and Geosciences, The Netherlands \\ ${ }^{2}$ RISSK, The Netherlands
}

\begin{abstract}
Producing more electricity from alternative sources may help to reach four goals: reduce $\mathrm{CO}_{2}$ and other emissions, compensate for depleting resources, reduce political dependency and replace an ageing and inefficient infrastructure. Billions of euros have to be spent in 'grey' or 'green technology to secure a reliable future supply of electricity. Producing electricity via photovoltaic (PV) systems has an Achilles heel: the sun is not a constant, reliable and manageable source of electric power like a fossil fuelled power plant. Variations in the supplied quantity and quality of electricity per unit of time may have economic (e.g. underutilisation of factories and rationing of consumption), physical (blackouts) and environmental penalties (if fossil fuel based back-up units temporarily 'kickin' to balance demand and supply). Several options might be considered to guarantee a reliable supply of electricity during an energy transition. A drastic increase in energy efficiency and energy saving measures is technically feasible and already happening at some scale. It may be the best solution for the environment, but it takes a long time and major investments.

Electric cars could be used for mobile storage of electrical energy; alone or combined with fixed storage.

The paper addresses 4 issues: the role of a buffer; the pros and cons for individual households of using grid-integrated electric cars; the potential for individual self-sufficiency; the remaining role of government.

Buffers are used in an electricity grid to balance demand and supply. Electric cars can fulfil a role as buffer in an electricity grid. This scenario does not provide a stimulus for major energy savings. The alternative scenario of selfsufficiency ('off-gridding'), in which solar PV systems and electric cars are
\end{abstract}


combined, is not feasible for an average Dutch household, yet. Under any scenario, the energy transition will change the role of government significantly. Keywords: electricity grid, electric cars and environmental impact.

\section{Introduction}

Climate change has profound implications for human consumption and production. Looking away from this major issue is only an option for those who still doubt the soundness of a stockpile of literature on climate change, have political or economic interests or like to buy time to wait for cheaper technologies to arrive.

Facing the issue wholeheartedly means adapting human consumption and production to climate change [1]. Technological innovations may support this complex, time-consuming and, without a doubt, also very expensive transition process.

Climate change is partially due to human emissions of $\mathrm{CO}_{2}$. This paper brings together two important causes of $\mathrm{CO}_{2}$ emissions, namely private car use and electricity production and consumption. Mobility is a basic necessity when distances between places are to be covered. One major disadvantage of mobility is its massive use of energy from non-renewable sources. Road transport (passenger and freight taken together) in EU-28 consumed 348.5 Mtoe in 2013, which corresponds to around $80 \%$ of all the final energy used by transport in EU-28. Over time it has slightly declined due to improved fuel efficiency. Fluctuations are due to economic swings, including the system crisis in 2008. Fossil fuel consumption leads to the emission of large amounts of greenhouse gases $\left(\mathrm{CO}_{2}, \mathrm{CH}_{4}\right.$ and $\left.\mathrm{N}_{2} \mathrm{O}\right)$. In 2012, transport in EU-28 counted for $10 \%$ all greenhouse gas emissions or 468.28 Mtoe in $\mathrm{CO}_{2}$ equivalents.

Electricity is also used extensively and again fossil fuels are an important power source. Countries in EU-28 consumed 71.1 Mtoe of electrical energy in 2013, which counts for $26.8 \%$ of the final energy consumption by households. Consumption of electrical energy is relatively stable since the year 1990. Its emissions of $\mathrm{CO}_{2}$ have also stabilized, despite economic growth, which points to a (partial) decoupling of economic activity and environmental damage. This trend is due to a higher efficiency of combustion and gas washing technologies in electric power plants (all data from [2]). Decoupling is a sign in the right direction, but the pace is too slow according to climate scientists [1].

The reliance or dependency on fossil fuels is changing due to two developments, which have taken off in many (developed) countries, viz. the introduction of various types of electric cars for (passenger) transport and the greening of the electricity production by electricity suppliers and consumers (prosumers). 


\subsection{Goal and research questions}

The research investigates the pros and cons of using electric cars as buffers in an electricity production system (network). It does so by addressing the following research questions:

1. What is the role of a buffer in an electricity network?

2. What are the pros and cons for individual households of using electric cars fully integrated in an electricity network?

3. Can individual households become (virtual) independent from the grid by installing solar PV panels and storing a temporary surplus of electricity in electric car batteries?

4. What will the future role of government be?

\subsection{Policy relevance}

This paper addresses these four research questions. The availability of data and familiarity with the local situation determined the focus on The Netherlands. If the data are available, a similar analysis could be carried out for other countries as well.

The potential buffer function of electric cars is one of the reasons why the Dutch national government subsidises electric driving. In its view stimulation of electric cars may help to [3]:

- $\quad$ Strengthen the Dutch economy;

- Improve the reliability of the Dutch electricity supply;

- Bring the Dutch $\mathrm{CO}_{2}, \mathrm{NO}_{\mathrm{x}}$ and $\mathrm{PM}_{\mathrm{x}}$ emission reduction targets closer.

There are suppliers to the car industry in other countries and there is a very small domestic production of cars and commercial vehicles. Nearly 25,000 cars were produced in 2012 [4]. Then Dutch car production dropped to insignificant numbers.

Electricity is used everywhere in the economy. A reliable electricity supply is a basic ingredient for welfare and representative for highly developed countries.

The average Dutch person travels nearly $11,000 \mathrm{~km}$ per year, of which nearly $75 \%$ is as car driver or passenger [5]. There are over $8 \mathrm{mln}$ cars on the road in The Netherlands. It is the mode of passenger transport that is used generally and for most activities also dominantly. The car, its use, its infrastructure and its impacts are therefore very relevant for Dutch society.

\subsection{An innovative contribution to science}

A major reason why independent scientific research exists is its ability to critically review government or business policies, in particular if the policy under review may have substantial positive or negative impacts on society. At present, the number of electric vehicles is very small, but growing, at least in The Netherlands, mainly due to a special tax regime. The number of registered e-cars passed the 70,000 mark by the end of 2015; 9,000 of these were FEV (full electric vehicles) [6]. 
Science is known for its many branches and sub branches, which makes it difficult to assess an issue in an integrative way. Depth is preferred over width in many scientific papers and microscopic details dominate, yet the strategic perspective, with its 'why' and 'when' questions is frequently ignored. This paper is different as it brings together several branches of research, in particular the following:

- Analysis of electricity networks and the role of power electronics and storage in the greening of the electricity supply and its implications for energy supply, business policy and public policy

- Innovations in vehicle engine technology (electric cars);

- Choice and use of cars, PV panels and fixed storage units (consumer behaviour, willingness to pay).

Carrying out such a project on a grand scale is typically the arena of consortia of large consultancies, universities and business (see e.g. [7]). Our small research resources prevented such an approach. Instead we deal with the micro level, i.e. the individual household with its private car and consumption (and production) of electricity. From an operational perspective this is actually much more interesting, because it is there where choices and impacts are most felt, hence the feasibility of a policy can best be assessed.

\subsection{Set-up}

The paper continues with section 2 (The system and the problem: electricity), followed by section 3 (Solution: full electric cars to balance the grid) and 4 (Conclusions and recommendations).

\section{The system and the problem: electricity}

\subsection{Introduction}

Section 2.2 provides a brief overview of Dutch electricity production and consumption. Section 2.3 sketches the impact of solar PV on the grid. This is followed by the discussion of a solution - grid balancing - in section 2.4.

\subsection{Dutch electricity production and consumption}

In 2013, 96.8 TW of electricity was produced in The Netherlands [2]. As can be seen in Figure 1, methane (natural gas) and coal were the prime sources of electricity production. Alternative sources (solar PV and wind) count for $10 \%$. There are a few small hydropower units. Nuclear power is available, but its future is uncertain. The use of methane for heating and cooking is on the decline, due to the growing use of high efficiency combi boilers in houses (now 85\%) and better insulation. Factors like less people per household and a higher labour participation of women are also important, yet not explicitly quantified. Cooking has increasingly become electric. Average use of gas $\left(\mathrm{CH}_{4}\right.$ or methane) per household declined from 1.747 to $1.341 \mathrm{~m}^{3}(-23 \%)$, while consumption of 
electricity per household went up from 3.378 to $3.495 \mathrm{kWh}$ per year (3.5\%) since the year 2000. This translates to a national (and also EU) average of 60 GJ per household. There is however a large spread around these domestic averages, due to differences in household size, house size, number and efficiency of electrical equipment, insulation quality and user behaviour. Consumers consume about $25 \%$ of all gas and electricity in The Netherlands [12].

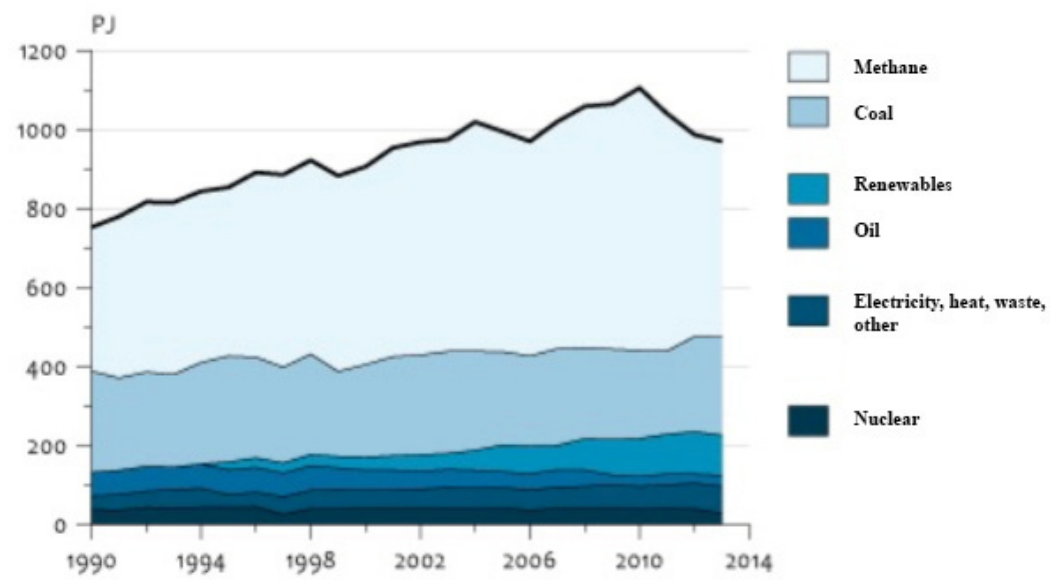

Figure 1: $\quad$ Sources of electricity production [9].

\subsubsection{Future outlook}

A discussion of the future Dutch electricity production and consumption requires an extensive and time-consuming analysis of many local and foreign factors, which is beyond the scope of a paper. Instead, a few interesting trends will be mentioned that are happening around the globe.

Solar PV is likely to become much more important in the future, hence the specific upward trend in Figure 1 is likely to continue, because of the dramatically falling prices of solar PV systems. Between 2005 and 2014 prices dropped from 40 to 9 euro cents per $\mathrm{kWh}$. In sunnier parts of the world even lower prices are found. A reduction towards 4-6 (2025) and 2-4 euro cents (2050) is regarded as conservative. Then solar PV will become the lowest cost power source if local regulators do not increase cost, and financial means are available to support this trend [10].

Second, a growing number of consumers and businesses have experienced that PV is a cost-effective and profitable way to generate electricity [11]. Several European governments subsidize purchase of solar PV systems, which increases economics of scale, lowers production cost and consumer prices of such systems. On their part, electricity companies pay a "prosumer" when he or she feeds solar PV generated electricity back into the grid.

Third, many fossil fuel operated power plants in Europe will be closed, because of technical or economic end-of-life. 
Fourth, many countries plan to expand production of wind energy as well. Germany and Denmark are actually exporting electricity surpluses at rockbottom prices. Gas used to produce electricity in power plants is now more expensive than (imported) electricity in The Netherlands, which leads to underutilisation or closure of such plants. Still, many off- and onshore wind parks are being developed or undergoing planning reviews.

Finally, green is booming and there is no discussion about a trade-off between solar PV or wind power nor what would be their most efficient location. There is also no (international) coordination, either in a financial or a technical sense in any of these cases. Spending money without a grand design seems rather risky, because billions of euros of taxpayer's money are spent on an energy transition without a good insight into the consequences of such a transition, and this while economies are struggling worldwide. Future energy scenarios also do not see a huge role for solar PV, which is also risky [14].

\subsubsection{Local distribution-connected PV installations}

The market for solar PV is clearly booming. In the year $2012344 \mathrm{MWp}$ was available and in 2014 this tripled to $1123 \mathrm{MWp}$, making Holland no. 18 in the world. China had $28 \mathrm{GWp}$ and USA $18 \mathrm{GWp}$ in operation in the same year. A further rise towards $10 \mathrm{GWp}$ is expected for The Netherlands by 2023 [15].

\subsection{Impact of solar PV on the grid}

This impact may be substantial [10]:

- There could be much more voltage variability in the distribution networks of providers who have an obligation to deliver a relatively stable voltage. This will occur in particular due to (rapidly) changing atmospheric conditions, when load on (= use of) the network is low, many solar PV installations are clustered and unevenly spread over the network;

- Solar PV systems are designed for maximum output. Its owners have no incentive to regulate their output if they get paid for feed-in into the network, as is happening in The Netherlands. Technical means, other than switching off the whole solar PV system, do not exist;

- Normally, variability at the network side is controlled by electromechanical voltage regulating devices. In case of PV solar without VoltAmpere Reactive (VAR) power compensation at the prosumer side (VAR is uncommon in the US, but obliged in Europe) excessive variability stresses these devices beyond their design specs (response time and voltage differential). Their lifecycle is then reduced by $60-80 \%$ (of/instead of 30 years). There are higher service needs and unanticipated costs, while the cause of the problem is not tackled. Experts speak of a (potential) domino effect of solar PV on the grid. In Europe, VAR equipped devices may reduce this impact to some extent. Voltage variability may be less, but stress on the low low and medium power grids calls for expansion; 
- There are less means of regulating the supply of energy to the grid, because operators cannot swiftly switch off sun or wind 'modules' as they can with a unit in a conventional power plant;

- There are uncertainties with respect to delivery and price of electricity, because there will be more flexibility, with many small suppliers instead of a few mega suppliers. The latter are also in the woods, because large investments have to be made in networks, while their income is declining. Network owners/managers have to invest billions in network extension. The market for electric energy production is changing completely [14].

\subsection{Solution: grid balancing}

In $100 \%$ fossil fuel based electricity networks, quantity and quality of electricity is managed by regulating output per power plant per unit of time and if necessary by rerouting electricity through the grid. With PV solar (and wind power) from a variety of local and foreign sources, the situation for power regulation becomes much more complex.

When looking into solutions, the following, non-extensive, list is interesting:

1. Continue to use fossil fuel power plants as backup. This means a more stable power supply, but there is an environmental penalty, namely the continued use of fossil fuel and its emissions;

2. Employ power electronics technology; VAR devices can be installed at the network and at the prosumer side. SCADA (supervisory control and data acquisition) systems can be used to monitor the grid more extensively [13];

3. Use car batteries for temporary storage of excess amounts of electric energy and to dampen the impact of large amounts of feed-in from solar PV systems on the grid.

There is no intention to calculate the exact size of the 'gap' between demand and supply or the varying quality of the electricity supply. Hence the paper will not go into investment or operational scenarios to solve the gap. This is because the gap is determined by a large set of factors. On the supply side one finds the amount, reliability and composition (grey/green) of nationally produced energy and locations where it is produced. Electricity (grey/green) can also be imported.

Momentary available power is determined by many factors, including technical, atmospheric, organisational and financial ones. The gap is also dynamic over time (day/night, season).

Grid balancing is needed to secure a stable delivery of electric power to (end) users under normal load. Then power is available at the required moment and quantity, while voltage (V), ampere (A) and frequency $(\mathrm{Hz})$ are maintained at a (fairly) stable level. Wider variations in these parameters may damage electrical equipment at home or at business units and voltage transformers at nodes in the networks. A stable grid is therefore a major condition for welfare.

The Dutch electricity grid still has a reliability of $99.995 \%$, which means that there is an extremely small change of power outages. In 2013, households were 
only 23 minutes without electricity, which is well below the average European 71 minutes [8].

Options 1 and 2 will not be considered in this paper. Elaboration of option 3 takes place from section 3 onwards.

\section{Solution: full electric cars to balance the grid}

\subsection{Introduction}

This section first starts with a short introduction into car use in The Netherlands (section 3.2), followed by a section explaining the logic of using electric cars as buffers in an electricity grid (section 3.3) by introducing 2 scenarios. Section 3.4 is used to elaborate one of these scenarios.

\subsection{Car use and emissions in The Netherlands}

Yearly mobility was $184 \mathrm{bln} \mathrm{km}$ in The Netherlands in the year 2014. In the same year private transport means (of which cars are the most important) emitted 19 bln $\mathrm{kg}$ of $\mathrm{CO}_{2}\left(+30.5 \%\right.$ since the year 1990), $38.9 \mathrm{mln} \mathrm{kg}$ of $\mathrm{NO}_{\mathrm{x}}(-75 \%$ idem) and $6.4 \mathrm{mln} \mathrm{kg}$ of $\mathrm{PM}_{10}(-47 \%$ idem). Emission reductions come from stricter emission standards, which led to more fuel efficiency, and improvements in catalysers [15]. The number of cars has grown over time due to a growing female workforce and a reduction in the number of car passengers. These behavioural and technical developments led to mentioned changes in emissions [16]. Table 1 presents the emissions to the air by individual cars.

Table 1: Fuel consumption and emissions by medium size cars (2015).

\begin{tabular}{|l|c|c|c|c|c|}
\hline $\begin{array}{c}\text { Tank-to- } \\
\text { wheel } \\
(\mathrm{TTW})\end{array}$ & $\begin{array}{c}\text { Petrol } \\
\text { VW Golf } 1.2\end{array}$ & $\begin{array}{c}\text { Diesel } \\
\text { VW Golf } \\
1.6 \mathrm{D}\end{array}$ & $\begin{array}{c}\text { PHEV petrol } \\
\text { Toyota Prius }\end{array}$ & $\begin{array}{c}\text { PHEV diesel } \\
\text { Volvo V60 }\end{array}$ & $\begin{array}{c}\text { FEV } \\
\text { VW Golf-e }\end{array}$ \\
\hline $\mathrm{Litre} / 100 \mathrm{~km}$ & 5.6 & 3.8 & 3.6 & 3.5 & \\
\hline $\mathrm{kWh} / 100 \mathrm{~km}$ & & & 3.7 & 4.3 & 16 \\
\hline $\mathrm{CO}_{2}$ & 132 & 101 & 107 & 119 & 97 \\
\hline $\mathrm{NO}_{\mathrm{x}}$ & 0.024 & 0.418 & 0.019 & 0.407 & 0.080 \\
\hline $\mathrm{PM}_{10}$ & 0.002 & 0.098 & 0.002 & 0.091 & 0.002 \\
\hline
\end{tabular}

Note: no supplier builds all types, hence these relatively comparable cars [17].

\subsection{The logic of using electric cars as buffers in an electricity grid}

There are two principally different ways of using electric cars in an electricity grid:

1. Grid-oriented/top-down, where millions of cars are used as buffers;

2. End-user oriented or bottom-up. In this scenario the end user only cares for his/her own power demand and invests in such a way that (virtual) isolation from the grid may come closer. 
Governments, large electricity suppliers and large business users prefer scenario 1 , because it maximizes tax income, continues the dependency of final consumers and continues the subsidization of large consumers by small consumers. This status quo scenario contains no economic incentive to reduce the consumption of electrical energy, which is the most effective way of reducing $\mathrm{CO}_{2}$ and other emissions [18].

Furthermore, maintaining and modernising an electricity grid requires billions of euros per year. It is important that these investments are spent effectively and not be written off too quickly because the strategy behind these investments was wrong. The large networks and the cross-border connections are now the preferred field of the large operators and governments, which is questionable, also because of their geo-political- and cyber security risks.

In The Netherlands, the national grid can absorb $20 \mathrm{GW}$ of solar PV without creating congestion. In 2013, $0.7 \mathrm{GW}$ was installed, while the $4 \mathrm{GW}$ mark may be reached in 2020. A maximum of $66 \mathrm{GW}$ could be reached if all roofs in The Netherlands would be covered with solar PV and these systems could be used at their full potential. This $66 \mathrm{GW}$ equals the energy demands of the built environment in The Netherlands [19]. In practice, solar PV systems reach at most $8 \%$ of their maximum power delivery [8], which is very (space) inefficient. This is due to seasonal and day cycles, the distance between the country and the equator, the non-optimal orientation of many solar PV systems towards the sun and weather conditions. To use solar PV more efficiently, large seasonal storage units could be installed, but these units are very expensive. Capacity expansion of the low and middle voltage networks and smart grid technology [20] may achieve the same, but is likely to cost much less.

In the second scenario, small users may (eventually) be disconnected from big users and large network facilities and only pay for what they consume. This scenario seems more fair and likely to score better in terms of energy savings and emissions. This is why this scenario will be elaborated in section 3.4.

\subsection{Individual households contribution to balance the grid}

Policy makers usually consider issues at the macro level and formulate their policy measures in a top-down fashion. The consequences for individual households (the micro level) may then be ignored or taken too lightly.

There is more, because a government can only partially influence household behaviour with a top down policy if the right economic incentives fail to exist. At the same time, by keeping the actual energy infrastructure $a s$-is, a government may frustrate the desire of individual households to become more sustainable.

Probably the highest level a sustainable household can reach is to become a modern 'off-gridder'. However, individual households may be faced with a dilemma at current prices: does their budget allow them to invest in solar PV and green mobility (by buying and using an electric car)? Demand for solar PV systems is growing over time due to falling prices and government subsidies. For electric cars, the situation is still different. E-mobility will only takeoff with lower purchase prices, either by subsidization or larger sales leading to lower 
production costs. Still, the problems of limited range and lack of en-route loading facilities have to be solved. Then, more of such cars will be bought.

With solar PV and electric cars even an off-grid scenario might be possible.

\subsubsection{A tentative scenario}

Daily direct energy consumption by a household consists of running a household and mobility. Suppose an average household uses $3340 \mathrm{kWh}$ per year [26]. It takes 16 solar PV units of $250 \mathrm{Wp}$ to produce $3500 \mathrm{kWh}$. This gives a surplus of $160 \mathrm{kWh}$ per year or $0.45 \mathrm{kWh}$ per day (or $4.5 \%$ ) for storage and/or use outside the home. If 2-way vehicle-to-grid (V2G) connectivity would be widely available (which is not the case, yet), this energy could be stored in car batteries.

Cars with combustion engines produce emissions. In a very optimistic scenario for electric cars (10\% FEV's on the roads, $100 \%$ green electricity, less diesels and more petrol cars due to the current tax regime which works against diesel cars), a reduction of about $10 \%$ in $\mathrm{CO}_{2}$ emissions could be obtained [11].

On average, commuters live at a distance of $14 \mathrm{~km}$ away from work [17]. Commuting is not the only demand for mobility. On average a distance of $24.8 \mathrm{~km}$ is traveled per day [29] one way. Overall, this adds up to about $50 \mathrm{~km}$ per car per day.

If a VW Golf-e represents a typical FEV, the energy buffer needed at the start of the journey of $50 \mathrm{~km}$ a day with an electricity consumption of $0.16 \mathrm{kWh}$ per $\mathrm{km}$ (see Table 1), is $8 \mathrm{kWh}$. This gives a deficit of $7.55 \mathrm{kWh}$ of homemade green electricity, which should come from extra solar PV panels. The earlier mentioned number of 16 solar PV units is already above the average Dutch number of 10 solar PV panels per roof. Either there is no space on an average Dutch roof to install extra units or they should be installed at less energy efficient directions or angles. Then there are the finances needed to buy these panels.

There are other issues as well. Batteries and solar PV panels degenerate over time [22]. Car lights, the entertainment system and the climate control system also deplete car batteries (rapidly). Winter conditions reduce battery power as well. This means that the driving range may drop by $50 \%$ or more. Additional energy is needed to recharge the batteries. This can only come from the grid. Fully recharging an FEV with current solar PV technology is not a realistic scenario, yet.

\subsubsection{Extension}

Instead of FEV's, so-called hybrids, being an electric vehicle with a small battery pack and a normal petrol or diesel engine (range extender) could be used in another scenario. Their combustion engines have become nearly as clean as those of fossil fuel powered electricity plants. They may act as mobile power plants with energy storage capacity in a green household. This option will be explored in a follow-up paper. 


\section{Conclusions and recommendations}

The main outcomes of this paper are the following:

- Buffers are used in an electricity network to balance demand and supply in terms of quantity and quality;

- Electric cars can fulfil a role as buffer in an electricity grid. Unless specific conditions (smart grid) are created, this technical solution does not solve the behavioural problem of inefficient use of/overconsumption of electricity leading to a non-sustainable level of $\mathrm{CO}_{2}$ and other emissions, however;

- An off-grid scenario consisting of individual solar PV systems and electric cars as mobile storage system is not realistic with current technology, the required space and the investments needed;

- Under any scenario, the role of governments may change significantly. Policy makers may either cooperate with or go against consumers (and companies) willing to invest in greener electricity. In any case, billions of euros are needed to secure a stable electricity supply.

It would be interesting to explore the following (combinations of) subjects for further study:

- Use of hybrid electric cars as mobile storage;

- Use of fixed batteries next to car batteries;

- Potential to increase the power density $\left(\mathrm{W} / \mathrm{m}^{2}\right)$ of solar PV systems and batteries;

- The impact of large communality solar PV systems on the grid and options for grid independent living;

- Potential for a reduction in electricity consumption per household;

- Introduction of smart grid technology at community level.

\section{Acknowledgements}

This paper is part of our joint research into options for society to make consumption and production in general, and transport and logistics in particular, more sustainable. The first author is also a member of the recently started Sustainable Transport Cluster within the Transport and Planning Department of his Faculty. We like to thank the anonymous reviewer for his or her efforts.

\section{References}

[1] IPCC, Climate change 2014, Mitigation of climate change, Working Group III Contribution to the Fifth Assessment Report of the Intergovernmental Panel on Climate Change, Cambridge University Press, Cambridge, USA, 2014.

[2] All data from Eurostat, Energy Transport and Environmental Indicators, Edition 2015, Luxembourg. 
[3] Rijksoverheid, Elektrisch Rijden in de versnelling, Bijlage 2: Plan van Aanpak 2011-2015, Den Haag, 2015.

[4] OICA, http://www.oica.net/category/production-statistics/2012-statistics/

[5] CBS, Transport en mobiliteit 2015, Den Haag, 2015.

[6] RVO, http:/www.rvo.nl/onderwerpen/duurzaam-ondernemen/energie-enmilieu-innovaties/elektrisch-rijden

[7] Essen, H., Kampman, B., Impacts of Electric Vehicles - Summary report, Delft, CE Delft, 2011.

[8] ECN, Energie-Nederland and Netbeheer Nederland, Energietrends 2014, Petten. All mentioned household data are from this source.

[9] CBS, PBL, Wageningen UR, Inzet energiedragers en bruto elektriciteitsproductie, 1990-2013 (indicator 0019, versie 20, 8 juni 2015). http://www.compendiumvoordeleefomgeving.nl

[10] Fraunhofer ISE, Current and Future Cost of Photovoltaics, Long-term Scenarios for Market Development, System Prices and LCOE of UtilityScale PV Systems, Study on behalf of Agora Energiewende, Berlin, 2015.

[11] Vleugel, J.M., Bal, F., Minder $\mathrm{CO}_{2}$ : Koop ik een elektrische auto of een set zonnepanelen? Bijdrage aan het Colloquium Vervoersplanologisch Speurwerk, 20-21 November 2014, Eindhoven.

[12] Solar Engineers, Geinstalleerd PV vermogen in NL naar 1,5 GWp, http://www.solarengineers.nl/nieuws/artikelen/288/Ge\%C3\%AFnstalleerdPV-vermogen-in-NL-naar-1,2 GWp.

[13] McDonald, J., http://powerelectronics.com/power-electronics-systems/ solar-power-impacts-power-electronics-smart-grid

[14] Geus, M. de, Naar een toekomstbestendig energiesysteem voor Nederland, Managementsamenvatting, TNO, 2015.

[15] CBS, Emissies naar lucht door de Nederlandse economie; nationale rekeningen, 18 januari 2016, Statline, http://statline.cbs.nl/StatWeb/ Emissies_naar_lucht (230116173242.xlsx).

[16] Ministerie van Infrastructuur en Milieu, Mobiliteitsbeeld 2015, KIM, Den Haag, 2015.

[17] Bal, F., J. Vleugel, Elektrisch autorijden: Waarom geen maatschappelijke discussie? Bijdrage aan het Colloquium Vervoersplanologisch Speurwerk 19-20 November 2015, Antwerp.

[18] Trias energetica, http://www.triasenergetica.eu/

[19] DNV.GL, Sterke groei van zonne-energie in Nederland mogelijk zonder overbelasting van het net, www.dnv.nl/nieuws_events/nieuws/2014/ zonnestroom.asp

[20] Overlegtafel Energievoorziening, Nieuwe spelregels voor een duurzaam en stabiel energiesysteem, Den Haag, 2015.

[21] Nu.nl, www.nu.nl/economie/2894647/Nederlander woont gemiddeld 14 $\mathrm{km}$ van werk.html

[22] Oldekater, M-J., Geurs, K., Hoogendoorn-Lanser. S., Vervoerwijzekeuze in woon-werkverkeer, Tijdschrift Vervoerswetenschap, 51(4), 2015. 